\title{
The Big Mac Index: A Shortcut To Inflation And Exchange Rate Dynamics? Price Tracking And Predictive Properties
}

Luis San Vicente Portes, Montclair State University, USA Vidya Atal, Montclair State University, USA

\begin{abstract}
The Economist magazine has been publishing the Big Mac Index using it as a rule of thumb to determine the over- or under-valuation of international currencies based on the theory of Purchasing Power Parity since 1986. According to the theory, using the Big Mac as a tradable single-good basket, the Dollar-value of the hamburger should be equalized around the world due to arbitrage. The popularity and following of the Big Mac Index led the authors to the following two questions: 1) How effective is the Big Mac price as an indicator of overall inflation? and 2) how accurate are exchange rate movement predictions based on Big Mac prices? They find that Big Mac prices tend to lag overall inflation rates, which is highly important in studies that use Big Mac prices as measures of affordability or real incomes over time. As a guide to exchange rate movements, there is support for the theory of Purchasing Power Parity, but only as a qualitative indicator of movement in the nominal exchange rate in rich and economically stable countries, proving less effective in forecasting exchange rate movements in emerging markets. The statistical analysis is carried out using data from 1986 to 2012 from The Economist and from the World Bank for 54 countries. The importance of these findings lies on the widespread use of the index and thus perpetuation of perceptions on the relative value of currencies in the areas of corporate finance, international trade and finance, and international business.
\end{abstract}

Keywords: Big Mac Index; Purchasing Power; Exchange Rate Dynamics; Inflation

\section{INTRODUCTION}

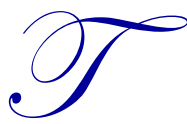

he Big Mac Index has been serving a notional rule of thumb regarding the valuation of national currencies with one another and mostly with respect to the U.S. Dollars. Founded on the principle of Purchasing Power Parity (PPP), a Big Mac hamburger serves as a homogeneous, representative tradable good for which the theory of PPP exchange rate could be applied -with all its caveats.

The purpose and contribution of this study is to explore the predictive power of the Big Mac Index and the attributes of Big Mac prices as a proxy for overall price movements. The latter is particularly important when used as a measure of real income and for real exchange rate dynamics, which depend on both countries' inflation rates.

PPP establishes that the "Dollar" price of a common basket of traded goods should be the same between two countries or else arbitrage from one market to another would shave the difference away. Consider the basket to be a Big Mac hamburger, which sells at 4 U.S. Dollars in New York and costs 2 Pounds Sterling in London, and the exchange rate between the Dollar and the Pound is two to one. In such a case, the U.S. Dollar price of the hamburger in the U.K. is 4 U.S. Dollars (2 Pounds x 2 Dollars/Pound) where PPP holds. What if the exchange rate were 1.50 Dollars per Pound? Then the Dollar price becomes 3 in London and arbitrage ensues until the exchange rate rises to 2 U.S. Dollars per Pound Sterling.

The ease and transparency of such calculations have made the Big Mac Index a sort of "back-of-theenvelope" way to forecast foreign exchange price movements as a long-term target for currencies to reach. Frequent 
updates by The Economist magazine not only champion the approach, but references to its pedagogic appeal can be found in textbooks and international organizations' publications. Hoefert and Hofer (2006) found out how many hours an average worker had to work to earn enough to buy a Big Mac burger in a country to demonstrate the existence of wage-rate disparity across countries. Atal (2014) found out the per capita Big Mac affordability across countries to measure the per-capita real income disparity and Daley (2008) related Big Mac prices to investment returns. Politi (2011) mentioned that Argentina's government was controlling Big Mac's price and indicated that they might have been manipulating their economic data.

In this paper, the authors study how effective the Big Mac price is as an indicator of overall inflation and how accurate exchange rate movement predictions are based on Big Mac prices. Using data from 1986 to 2012 from The Economist (for Big Mac prices) and from the World Bank (for inflation series) for 54 countries, it is found that Big Mac prices lag overall price movements. A comparison is made between the co-movement of the Consumer Price Index (CPI) and the Big Mac, vis-à-vis the GDP deflator, the broadest measure of prices in an economy. An important finding is the degree of "stickiness" in Big Mac prices. On the other front, as a gauge of currency valuations, the authors take a step back in time and see the relative valuation of the currencies against the U.S. Dollar five years before 2012 and measure the direction and degree of convergence in the currencies to their PPP benchmarks. In this regard, the record is mixed - about half of the currencies (either under-valued or over-valued) moved in the predicted direction.

In this paper, the authors describe the dataset and conduct a "tracking" exercise in which they assess to what extent Big Mac prices reflect overall price movements; they calculate the degree of under- or over-valuation of a set of world currencies and test whether their evolution tracks the dynamics implied by the Big Mac Index; and they provide a conclusion.

\section{PRICE TRACKING AND BIG MAC INDEX}

To conduct the experiments outlined above; namely, the co-movement of Big Mac prices with overall inflation rate and the predictive power, the authors used The Economist's proprietary Big Mac dataset that goes back to 1986 and the World Bank's World Development Indicators for the countries' CPI and GDP deflator. The authors merged these datasets to have the countries' Big Mac prices, nominal exchange rates, PPP exchange rates, CPI inflation, and GDP deflator inflation rate.

To measure aggregate price movements, the authors take a "bottom up" approach where the GDP deflator provides the broadest measure of prices in an economy. They then move up to the CPI and then to the Big Mac $-\mathrm{a}$ one-good basket. The premise of the analysis is that if all these price measures are perfectly correlated, then one would observe a 45 -degree line type of fit where a given change in one of the variables maps to the same change in the other variable when plotted together.

The analysis begins with a plot of the CPI against the GDP deflator. The sample includes countries with inflation rates of over 100 percent a year, but to avoid such unstable episodes weighing in the findings (on the more narrowly defined question) the authors limit the sample to GDP deflator inflation rates of 20 percent or less during the sample period. The change from one year to the next captures price changes in the corresponding basket of goods and those from the economy as a whole.

Figure 1 highlights two particular features: 1) the CPI does not completely track the GDP deflator - that is, it rises at a slower rate - and 2) the level of inflation matters for this relationship. The quality of the fit decays as inflation levels get higher. Between zero and five percent inflation rates, there is a tight fit; thereafter, every five percent increments in inflation rates reveal a weaker fit in a clear pattern of heteroskedasticity. With a sample of 626 observations, the regression line for this graph yields a slope coefficient estimate of 0.79 significant at the 1 percent level and an R2 of 0.68 . 


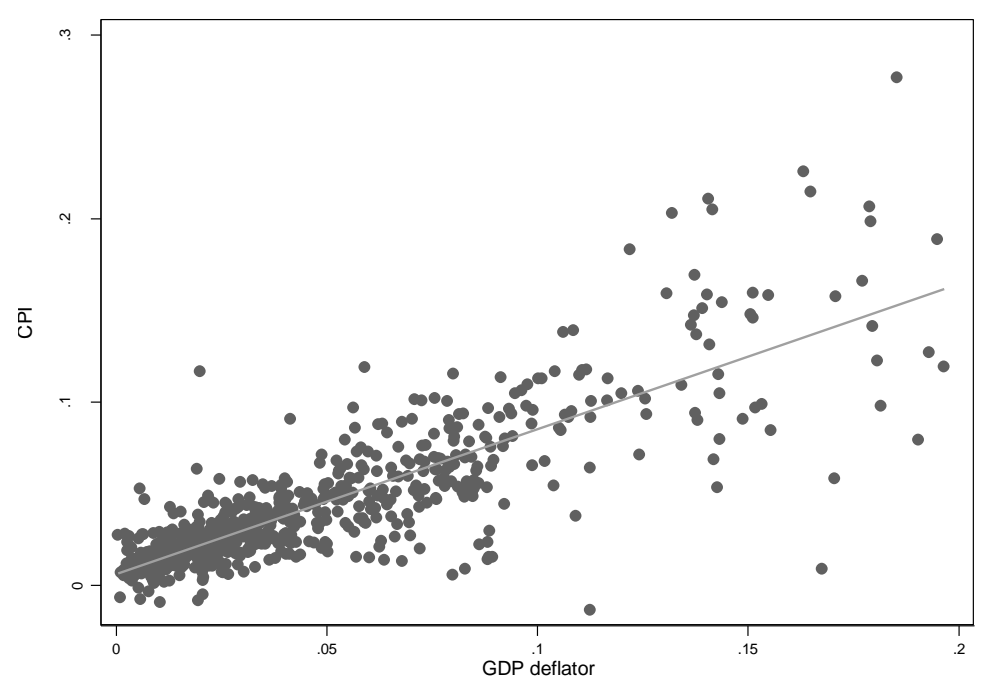

Figure 1: Tracking Inflation - CPI versus GDP Deflator

Next the authors turn to the analogous analysis of Big Mac prices relative to the GDP deflator, conditioning on inflation rates less than 20 percent, and Big Mac price changes greater or equal to zero. This is imposed since there were a few cases of lower Big Mac prices amid positive inflation rates which, by construction, would weaken any directional general relation of these price indices over time.

In contrast to the CPI, Figure 2 shows a weaker systematic movement in Big Mac prices compared to the overall price level. Furthermore, it shows a high degree of price stickiness at the one-year frequency. The degree of stickiness (i.e., zero Big Mac price change) is present even in the 15 to 20 percent annual inflation range. The number of observations in Figure 2 is 587 and the estimate of the slope coefficient is 0.73 significant at the 1 percent level and an R2 of 0.09 . The poorer "goodness of fit" can also be seen on the other margin - there are several low inflation countries that experienced large increases in Big Mac prices.

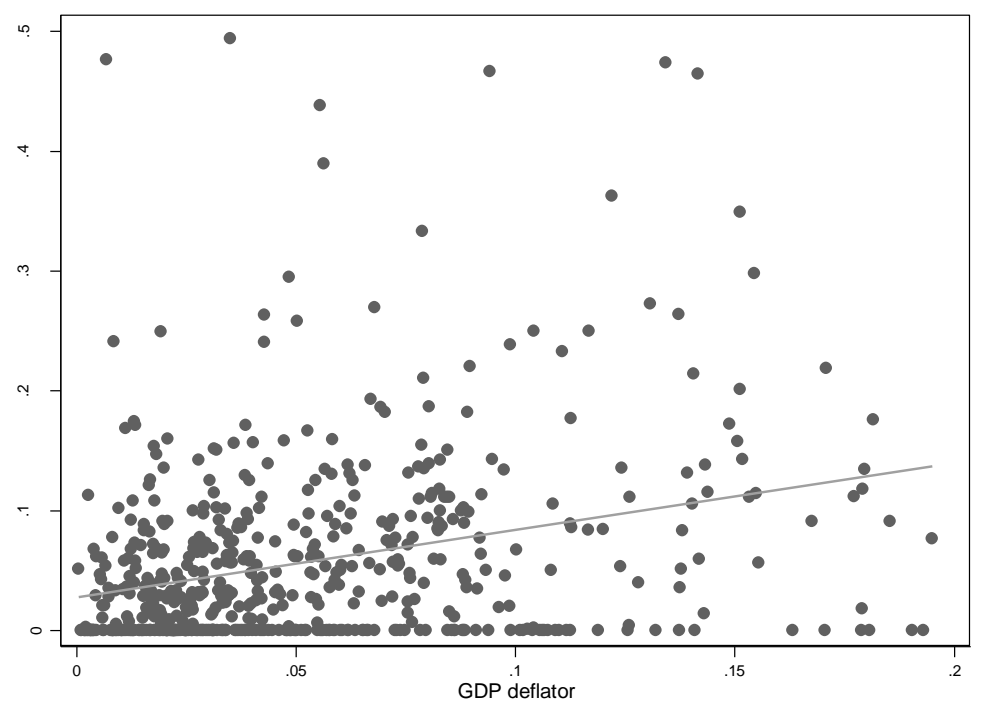

Figure 2: Tracking Inflation - Big Mac Prices versus GDP Deflator

Based on the findings above, it is important to note that studies or analyses based on the Big Mac index that bear a time dimension ought to be taken with caution, particularly if they seek to capture or proxy for any feature of 
aggregate price dynamics. The authors note, too, that cross-country comparison of affordability or real incomes at a point in time are not subject to such critique.

\section{EXCHANGE RATE DYNAMICS}

The findings from the previous section call into question the efficacy of the Big Mac Index as a predictive tool for currency fluctuations. To address this issue, the authors break the question into two. As a proxy for currency valuation, the Big Mac Index serves as a gauge if taken with its caveats, since contemporaneous comparisons ought not to be affected by its lagging relative to inflation as suggested in Figure 2. However, as a forecasting tool, there is potential for a large margin of error. How much? To answer this, the authors put the index to the test and contrast what the Index's prediction on currencies appreciating or depreciating were and what happened during the last five years of data in the sample.

To see a clearer detail of the mechanics of the Big Mac Index, Figure 3 presents a snapshot of the countries' currency valuation relative to the U.S. Dollar. The ratio of the U.S. Dollar price in local currency (i.e., the nominal exchange rate) to the theoretical PPP local currency price for U.S. Dollar provides a measure of under- or over-valuation, or parity of the country's currency against the Dollar. An overvalued (undervalued) Dollar is characterized with a ratio greater (less) than one, and parity would be exactly equal to one.

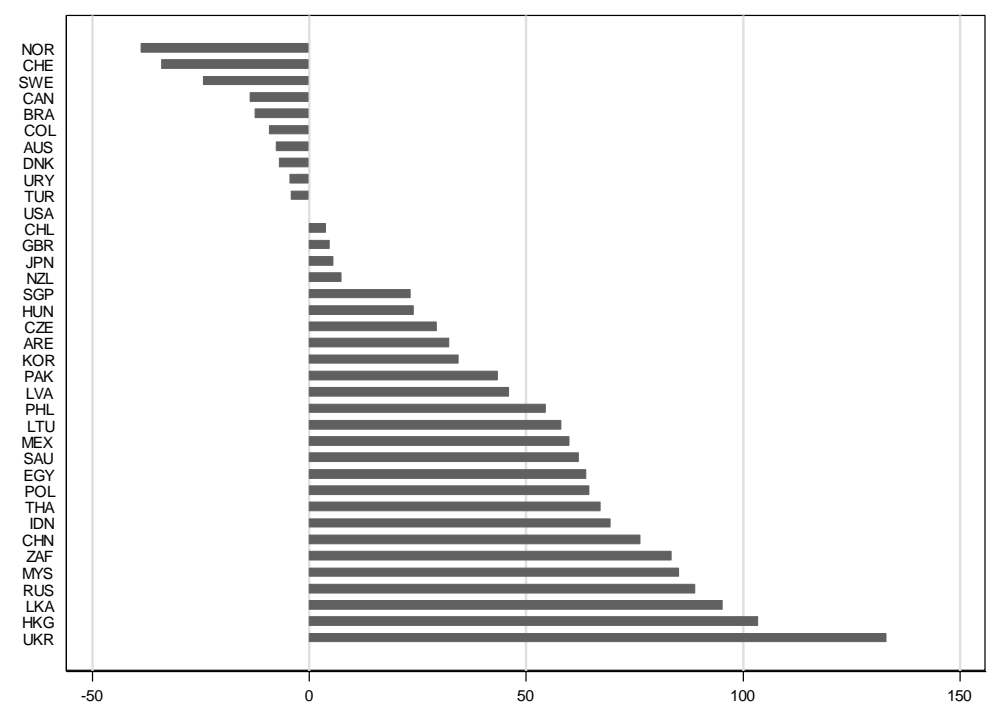

Figure 3: Percentage Difference of Nominal Exchange Rate to PPP in 2012

Figure 3 shows such valuations expressed as the percentage difference between the nominal exchange rate and the PPP exchange rate. Under this measure, the least undervalued currency is the Chilean Peso and the least overvalued currency is the Turkish Lira. By construction, there is parity in the U.S. Dollar. This figure suggests that, with time, undervalued currencies should appreciate and overvalued currencies should depreciate. Cheaper U.S. Dollar prices associated with weaker currencies should open arbitrage opportunities to buy in those countries and sell in the U.S.; greater demand for those local currencies should eventually bring them to parity. But is this the case?

To test whether this is the case, the last stop in the analysis concerns the predictive power of the Big Mac Index as an indicator of the direction of future exchange rate movements. The authors calculate the gap between the nominal and PPP exchange rates in 2007 and their gap in 2012 - the last year of the sample. During this 5-year period, the gap should have narrowed regardless of the currencies being either over- or under-valued.

Figure 4 presents such changes for the currencies that remained over- or under-valued throughout the period. For instance, the Chinese Yuan was $135 \%$ percent undervalued relative to the U.S. Dollar in 2007 and 76 
percent in 2012. This corresponds to a 59 percentage point change reduction in the gap between the Yuan and its parity value, a large appreciation. The Norwegian Krone, the most overvalued currency in the sample in 2012 , has been on a depreciation path, bringing it closer to parity. Like the case of Chinese Yuan and the Norwegian Krone, those currencies that moved closer to their PPP rates are on the top of the figure and report negative numbers that correspond to the absolute difference in 2012 compared to 2007. However, positive changes mean that the currencies were drifting away from their parity values. For example, the Mexican Peso increased its undervaluation by 33 percentage points and the Ukrainian Hryvnia by 48 percentage points. The split between converging and diverging currencies relative to the Big Mac implied that parity values raise a cause for concern and call into question when this index can be used as a guide. At first glance, the Big Mac Index works better in countries with more established and stable economies, like some non-Euro European countries; and, except for Canada, most divergence occurred in emerging markets.

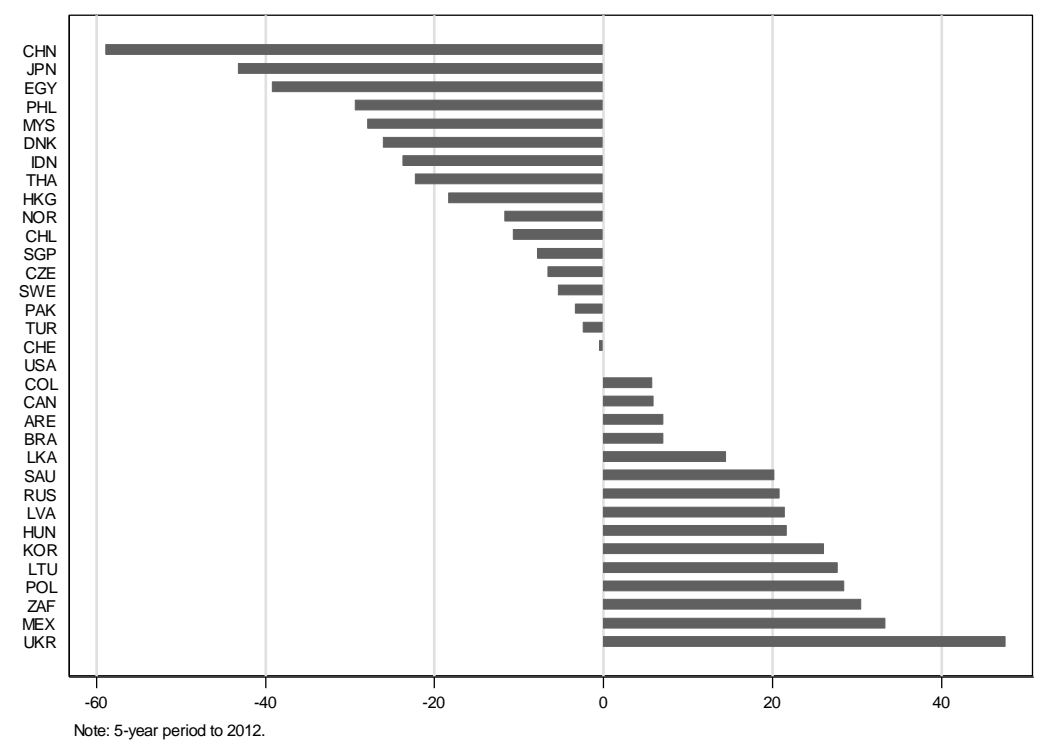

Figure 4: Exchange Rate Dynamics - Distance To PPP (Negative Implies Convergence and Positive Implies Divergence)

\section{CONCLUSION}

This study is set out to characterize the behavior of the Big Mac Index in terms of its price-tracking power and exchange rate predictability. These are mainly dynamic considerations and thus do not undermine the use of the index as a measure of cross-country affordability or real income comparisons. However, the authors find that Big Mac prices lag overall inflation and exhibit an important degree of stickiness in a 1-year horizon. As an exchange rate prediction tool, the authors find that, for a particular group of high-income countries, there is some forecasting power in the Big Mac Index as countries gravitate towards a PPP parity rate, but for a large group of emerging markets, their currencies' path diverged from parity.

\section{AUTHOR INFORMATION}

Luis San Vicente Portes is an Associate Professor at the Department of Economics and Finance at Montclair State University. He holds a Master's degree and a Ph.D. in Economics from Georgetown University and he earned his Bachelor's degree at the Instituto Tecnologico Autonomo de Mexico (ITAM). Dr. San Vicente Portes has worked as a consultant for the World Bank. Dr. San Vicente Portes' research focuses on macroeconomics and international economics and has been published in journals such as Quarterly Review of Economics and Finance, The Berkeley Economic Journal of Macroeconomics, The Global Economy Journal, and the Journal of Development Economics. Luis San Vicente Portes, Montclair State University, 1 Normal Avenue, Partridge Hall 328A, Upper Montclair, NJ 07043. E-mail: PortesL@mail.montclair.edu (Corresponding author) 
Vidya Atal is an Assistant Professor in the Department of Economics and Finance at Montclair State University. She holds a Master's and a Ph.D. degree in economics from Cornell University. Her research interests include studying the patent policies in USA, open source software licensing, firms' investment decisions in R\&D, etc. In addition, she finds several other topics like female power, intra-household bargaining, right to employment, very interesting. Dr. Atal's research articles have appeared in some of the top-tier peer-review journals, namely, the Journal of Industrial Economics, Economics Letters, International Journal of Industrial Organization, and International Journal of Economic Theory. Vidya Atal, Montclair State University, 1 Normal Avenue, Partridge Hall 427, Upper Montclair, NJ 07043. E-mail: AtalV@mail.montclair.edu

\section{REFERENCES}

1. Atal, V. (2014). The Big Mac Index and real-income disparity. Journal of Business and Economics Research, 12(3).

2. Big Mac Index (2012). Retrieved March 31, 2014 from http://bigmacindex.org/2012-Big-Mac-Index.html

3. Daley, J. (2008). Burgernomics: Why the price of a Big Mac may hold the key to better investment returns. The Independent.

4. Hoefert, A., \& Hofer, S. (2006). Prices and earnings: A comparison of purchasing power around the globe. UBS AG, Wealth Management Research, p. 11. Retrieved February 4, 2014 from http://www.ubs.com/ 1/ShowMedia/ubs_ch/wealth_mgmt_ch?contentId=103982\&name=eng.pdf

5. Politi, D. (2011). Argentina's Big Mac attack. The New York Times. Retrieved February 4, 2014 from http://latitude.blogs.nytimes.com/2011/11/24/argentinas-big-mac-attack/

6. The Economist (2014). Retrieved Janaury 31, 2014 from http://www.economist.com/content/big-mac-index 